\title{
工学系学生の苦手意識を克服し 自律学習へ導く英語多読授業
}

\author{
Extensive Reading Program Which Changes Reluctant Engineering \\ Students into Autonomous Learners of English
}

$\begin{array}{llll}\text { 西 澤 } & \text { —1 } & \text { 吉 岡 貴 芳※1 } & \text { 伊 藤 和 晃※1 } \\ \text { Hitoshi NISHIZAWA } & \text { Takayoshi YOSHIOKA } & \text { Kazuaki ITOH }\end{array}$

\begin{abstract}
This article introduces extensive reading (ER) as an approach to improve fundamental communication skills in English of reluctant EFL learners : average Japanese engineering students. It is distinct from concurrent translation approach from a perspective that the learners use English instead of Japanese to grasp the meaning of what they read and enjoy reading. In the ER program at Toyota National College of Technology, many students developed more positive attitude toward English, increased their reading speed, and achieved higher TOEIC scores, which was compared to those of the students before this ER program was introduced. Comparison between three groups of the students showed strong correlation between their TOEIC scores and the reading amount.

Keywords: Communication Skills, Effectiveness, English for Engineering, Engineering Education, College of Technology

キーワード：コミュニケーション，教育効果，科学技術英語，技術者教育，工業高等専門学校
\end{abstract}

\section{1.まえがき}

技術者が業務のために英語を必要とする度合いは高 まっているにも拘らず, 多くの工学系学生は依然とし て英語に苦手意識を持っており，英語教育は21世紀の グローバル社会に積み残した技術者教育の大きな課題 である.JABEE受審をきっかけに，多くの大学，高 専は，国際コミュニケーションの基盤となる英語運用 能力を確保しょうと多大な努力をしているが，期待さ れる成果が上がっている機関は多くないようである.

工学系学生の苦手意識を克服し, 卒業生の英語運用能 力を保証するためには, 運用能力向上のしくみと教育 手法を見直し, 新しい手法も試す必要がある.

そこで本稿では，工学系学生に対する英語教育の現 状を振り返り，「英語で考える」という視点からこれ を見直すことで, 現状改善への道筋を考えたい。 また， 学生が「英語で考える」ことを実現できていると考え られ, 学生の運用能力向上にも成果を上げつつある英 語多読授業の実践例を紹介する。

\section{2. 工学系学生の英語運用能力と英語教育改善の 取り組みの現状 \\ 日本の技術者教育の現場では，国際コミュニケー}

平成 22 年 1 月 20 日受付

※ 1 豊田工業高等専門学校
ションの基盤となる基礎的な英語運用能力をTOEIC で測定することが多い。一部の企業は社員の昇進基準 にTOEICを利用しており, 多くの高専は学生の英語 運用能力評価にTOEICを活用している ${ }^{1)}(57$ 校中 34 校 が受検を義務づけ，22校がTOEIC-IP実施). TOEIC は得点表示が細かく, 基礎的な英語運用能力の測定指 標として安定しており, 社会的認知度が高く, 難易度 が高すぎないことが，よく利用される理由であろう． 例えば, 英語圈での単独出張のサバイバル水準は600 点と言われ, 高専英語教員が卒業時に期待するのは約 500 点 $^{2)}(400 \sim 500$ 点が57\%, 500〜 600点が $29 \%)$ で ある. 修了要件に400〜450点を設定しているJABEE プログラムも少なくないが ${ }^{3)}$, その水準は, 修了生が 社会で英語使用を迫られたとき（逃げることなく）英 語学習を開始・継続できる最低レベルと考えてよかろ う。ただ，350点未満では回答スタイルの影響が大き くなり, 個々の学生がどれほど「できない」かを推定 することは難しくなる.

ところが，2008年度のTOEIC-IP試験の学系別全国 平均をみると ${ }^{4)}$, 理学・工学・農学系では395点 ( 3 年が最低) 415 点（ 4 年が最高）にとどまり, 学年 による上昇傾向が認められない, また, 高専では（大 学 4 年と同学年の) 専攻科 2 年の平均が 377 点とさら に低得点で, 期待する水準との乘離が大きく, 高専生 の苦手意識と符合する結果となっている. 
この現状を改善するために取られている工学系大 学・高専の取り組みは，大きく分けて五種類ある。第 一は, 文法・語裹学習や論文, 文献の輪講の充実等, 文法訳読による英語教育の強化であり，第二は，専 門科目の授業活動の英語化, 英語によるプレゼン等コ ミュニケーションを重視した活動の導入である．第三 は，TOEIC受験対策の授業であり，第四は，数週間 から数ヶ月の短期留学が中心となる国際交流活動であ る。また，第五が，本稿で紹介する多読授業である.

しかしながら，これら取り組みの成果をみると，学 生の動機付けに成功したとの報告は多いが，英語運用 能力の向上を測定できたとする報告は意外に少ない. また，選ばれた一部学生の運用能力向上例の紹介はあ るが，苦手意識を持つ学生も含めた大多数の平均的な 学生の英語運用能力を底上げし, 前述の水準を達成し たとの報告は，さらに少ない，

例えば，国際交流活動の動機付け効果は優れている が，短期間で英語運用能力自体が向上するわけではな い. 豊田高専では, 2008年度までの 3 年間に69名の本 科 $2 \sim 3$ 年学生が英語圈へ10 ケ月の交換留学をして いるが, 帰国後のTOEIC平均は605点である ${ }^{5}$. 留学 の目的は異文化体験であり，その価值は高く評価する が, 英語運用能力向上に限れば, 意外に効果は低い. このことから，3ヶ月以下の短期留学は, 英語運用能 力向上よりも動機付けが主眼と考えた方がよからう.

コミュニケーション重視の活動は, 比較的英語の得 意な学生は伸びるものの, 苦手な学生を積み残してし

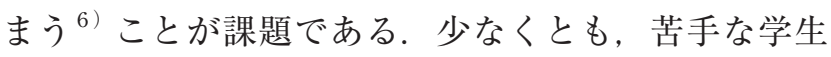
に対する教育手法を併用する必要がある.

TOEIC 受験対策授業は, 学習内容が無味乾燥で動 機付けが難しく, 学生の自律的な学習習慣を育てにく $\left(^{7)}\right.$. さらに, 学習内容が過去問の演習や, 受験対策 に偏ってしまうと, 得点上昇が必ずしも英語運用能力 の向上を伴わないのでは, との疑念も生ずる.

さらに, 従来教育の強化のみで運用能力を向上させ たとの報告は発見できず，工学系大学・高専の教育現 場では, 有効な改善手法を求めた試行錯誤が続いてい る。 そこで, 本稿では, 種々の改善手法を検討する際 の視点から見直し, 次章で検討したい.

\section{3. 工学系学生に対する英語教育の視点}

\section{1 対立軸は, 文法訳読かコミュニケーションか}

日本の英語教育に関する議論は，伝統的な文法訳読 を堅持すべきか，コミュニケーション重視の教育法 へ転換すべきかを対立軸に論じられることが多かっ た ${ }^{8)}$. LL教室の充実, Native 教員による会話の授業, 専門科目での英語利用, 国際会議での発表推奨等, 近 年の多くの取り組みは後者の試みである.

しかし, 工学系学生の英語運用能力を向上させるに は, 両方法ともカバーしていない領域に注目する必要
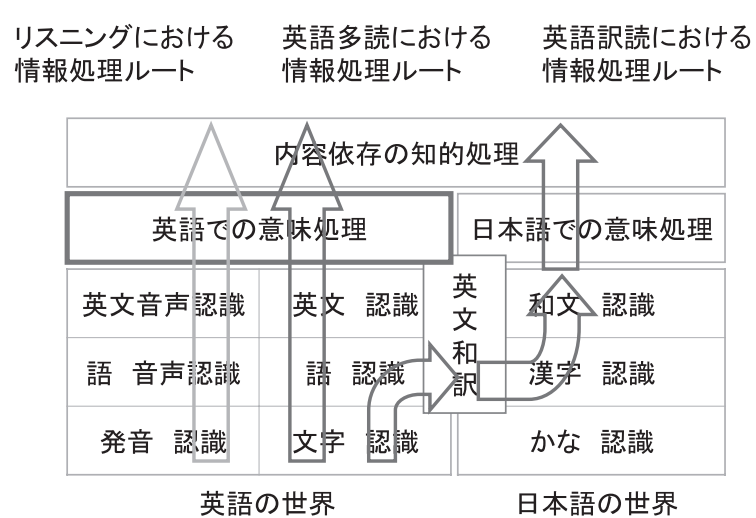

図 1 英語による情報処理ルート ${ }^{9)}$

がある，図 1 において，文法訳読が育成しているのは 主として「英文和訳」と「日本語での意味処理」であ り, コミュニケーション重視の教育法が育成している のは主として「英文音声認識, 英文認識」以下の領域 と考えられる.すなわち, 眓 1 の「英語での意味処理」 は, カバーできていない. 両方法とも学習者が「英語 で考える」能力を育成できていないのである.

文法訳読で蓄えられるのは（日本語で表現された） 英語に関する知識であり，しかも授業で教えたこと以 外を問わない定期試験では, その知識の丸暗記で合格 点が取れる ${ }^{10}$ 現状さえある（定期試験で既知英文を 使用すれば，和訳を一夜漬けで覚えて試験に臨む学生 が出現してもおかしくない)。また，「学校教育で与え るべき最低限の英語力」育成策が, 「文法, 読解, 素読, 暗唱などを含めた『型』の訓練」8)であるとしても,「英 文音声認識, 英文認識」以下の領域までしかカバーで きない.

コミュニケーション重視の教育法においても，実態 は学生が英文和訳, 和文英訳に強く依存しており,「英 語で考える」は実現できていないことが多い，例えば, ネイティブ講師の発言内容を学生が聴き取れないまま 授業が進行しており, また, 学生が発表原稿を丸暗記 してのプレゼンはできるが, 質疑応答には対応できな いのであれば，「英語で考えて」いるとは考えにくい. 学生が「英語で考える」ことを実現できていないこ とが, 現行英語教育の課題ではなからうか.

\section{2 英語で考える}

「英語で考える」ためのヒントは，第二言語習得の 分野に求めることができる. 例えば白井 ${ }^{11)}$ は, 「外国 語のメッセージを理解する, すなわちインプットが, 言語習得をすすめる上での必要条件だということで す。アウトプットが必要かどうか, という議論はあり ますが，インプットを理解することの重要性を否定す る研究者はいません.」と解説している. 理解可能な 内容英語を大量にインプットすることで, 学生が「英 語で考える」体験を積むことができれば, 従来の英語 教育との相乗効果により, 比較的短時間で英語運用能 力を向上できるのではなからうか. 


\section{3 必要な学習時間}

そこで，学生が「英語で考える」体験として必要と 思われる学習時間を, 留学経験者の例から試算してみ よう．例えば，TOEIC得点を350点（2008年度の高校 1 年平均が 357 点, 高専 3 年平均が 336 点 ${ }^{4)}$ ) から500 点（2008年度の大学 4 年全学系平均が 497 点）まで引 き上げるためには，何時間の体験が必要であろうか？ 前述した留学経験者のTOEIC得点が平均 605点である ことから単純に試算してみる. 留学期間中の英語使用 時間を 1 日 5 時間とすると, 留学経験者は 1,000 時間 でTOEIC得点を255点上昇させたことになり，学習時 間に対するTOEIC得点の上昇が直線的だと仮定する と500点（150点上昇）までには約600時間（留学期間 は 6 ヶ月）を要することになる。これを授業関連の学 習活動に換算すると，45時間／単位で13単位（30時間 ／単位で20単位) であり, 高校+大学, または, 高専 の現行開講単位数の範囲内ではあるものの, 授業時間 の大部分を費やすことになり, 他の英語学習活動を圧 迫してしまう。

これを避けるためには, 留学体験よりも濃密に「英 語で考える」学習活動，または，学生が授業関連時間 を超えて自律的に学習する活動を創出する必要があ る. 無味乾燥な訓練的活動の詰め込みではなく, 学習 活動そのものが楽しみ，息抜き，または，更なる学習 動機になる活動として,「英語で考える」学習活動を 実現したい.

\section{4. 多読授業の実践例}

そこで本稿では，学生が「英語で考える」授業を実 現できていると筆者が考える, 豊田高専電気・電子シ ステム工学科（以下 $\mathrm{E}$ 科と略称）の多読授業実践を紹 介する。この授業では, 学生が理解可能な英文を大量 に読んでおり，一定量（例えば30万語）の多読経験者 は「英語を読んでいるときに，あまり日本語が思い浮 かばない」と答える者の比率が高い ${ }^{9)}$. 多読授業では, インプット量を読書量 (累積語数) で測定しているが,

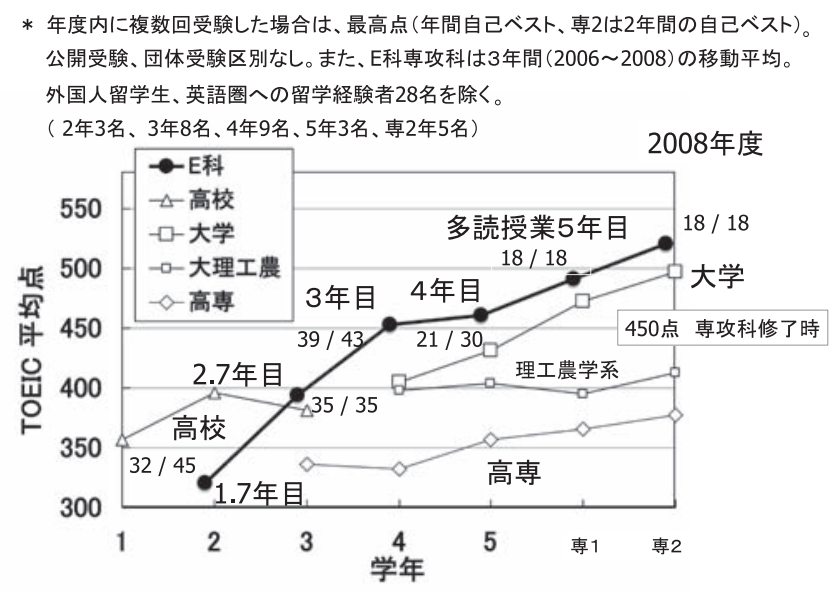

図 2 豊田高専 E 科学生のTOEIC平均点（2008年度）
13ないし20単位の授業関連時間：600時間の $1 / 3$ を読書 活動にあてれば，（毎分平均80語で）約100万語の英文 多読が可能である.

実際に 5 年間継続の多読授業（5 単位）を受講した 2008年度の豊田高専専攻科学生（18名）は，授業時間 内外の多読活動で累積101万語(中央値)の英文を読み, TOEIC平均518点を得ている ${ }^{12)}$. プログラム修了要件 の450点も, 高いハードルとは認識されていない（図 2 ).

豊田高専 $\mathrm{E}$ 科の多読授業は, 従来の英語教育カリ キュラムを変更することなく, 各学年 1 単位の多読授 業を専門科目として追加することで導入した（表 1 ). 多読授業は2002，2003年度に本科 5 年で試行し，2004 年度には本科 $2 \sim 5$ 年および専攻科 1,2 年の 6 学年 で一斉に拡大導入したため, 2008年度の専攻科 1,2 年生は, 同年度に継続 5 年目の多読授業を受講してい る.

表 1 専攻科学生の多読授業継続年数の推移

\begin{tabular}{|c|c|c|c|c|c|c|}
\hline 年度 & 2003 & 2004 & 2005 & 2006 & 2007 & 2008 \\
\hline 1 年 & $(1$ 年経験 $)$ & \multirow{2}{*}{2 年目 } & 2 年目 & \multirow{2}{*}{3 年目 } & \multirow{2}{*}{4 年目 } & 5 年目 \\
\cline { 1 - 1 } 2 年 & 多読前 & & 3 年目 & & & \\
\hline
\end{tabular}

（22.5時間 $\times 5$ 年）の授業時間内に読むことのでき る最低限の読書量は, 毎分 80 語で計算すると54万語に なるが，15人（83\%）がこれ以上を読んでおり，また 10人（56\%）が100万語以上を読んでいる（図 3 ).

学生は, 自律的な英文読書習慣を身につけており(日 本語に翻訳することなく読むことのできる英文のレべ ルを把握し, 適切な英文図書を選択, 授業時間内外に 読むことができている), また, 定期試験（初見英文 の読解試験）に合格し, 外部試験 (TOEIC) 得点も 上昇している. E 科専攻科学生のTOEIC平均点 (年 間自己ベストの平均, 英語圈への留学経験者を除く) を多読授業経験年数（表1）でまとめた（図4）.

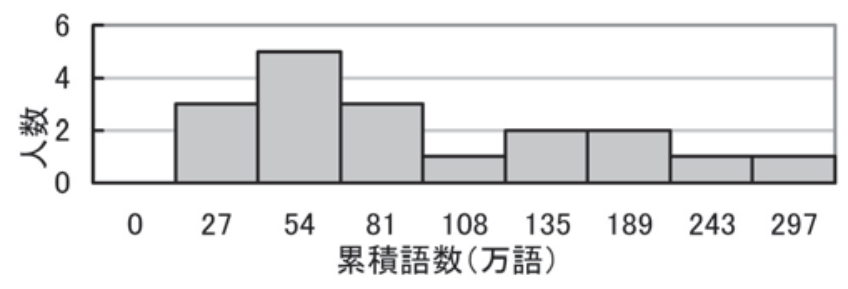

図 3 受講生の読書量分布 (中央值 : 101 万語 $)^{12}$

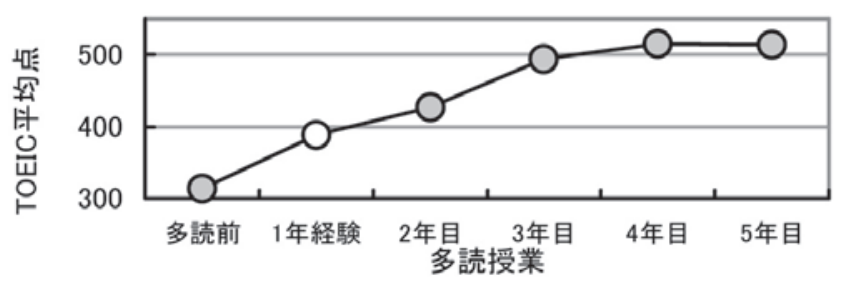

図 4 多読授業継続年数とTOEIC平均点の関係 
表 24 年間多読授業継続学生の群分け

\begin{tabular}{|c|c|c|c|c|}
\hline \multirow{2}{*}{ 群 } & \multicolumn{2}{|c|}{ 読書量（万語） } & \multirow{2}{*}{ 人数 } & \multirow{2}{*}{$\begin{array}{l}\text { TOEIC } \\
\text { (平均点) }\end{array}$} \\
\hline & 中央值 & 範囲 & & \\
\hline $\mathrm{A}$ & 31 & $28 \sim 39$ & 9名 & 435点 \\
\hline B & 66 & $49 \sim 82$ & 13名 & 498点 \\
\hline $\mathrm{C}$ & 181 & $107 \sim 1,200$ & 8 名 & 604点 \\
\hline 英 & （10ヶ月 & 留学者* & 69名 & 605点 \\
\hline
\end{tabular}

*2006～2008年度 3 年生

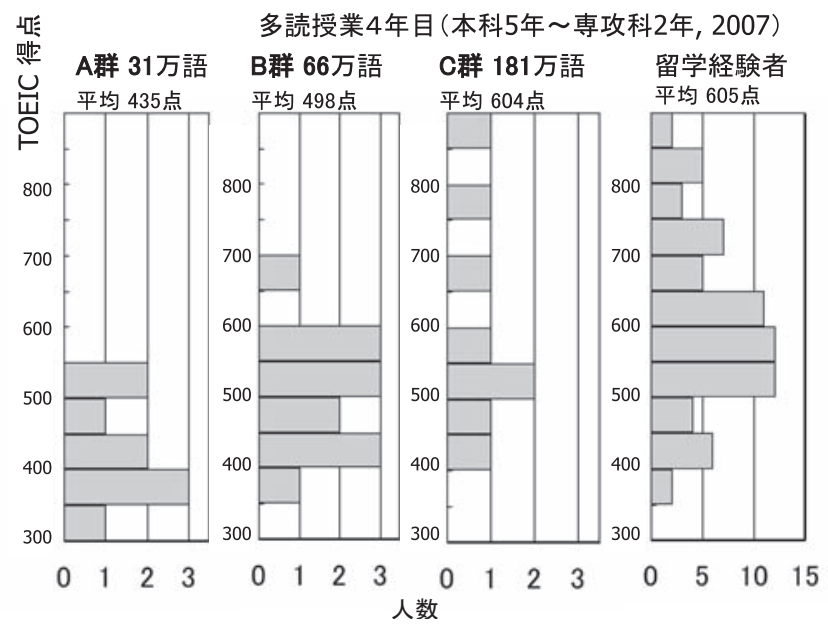

図 5 累積語数別のTOEIC得点分布 $(\text { 多読 } 4 \text { 年目 })^{5)}$

多読授業開始以前の 2003 年度（専攻科 2 年生）に対 し, 多読授業 $1 \sim 3$ 年でTOEIC平均点が徐々に上昇 し， 4 年目以降では平均 500 点以上で安定している.

次に, 読書量の違いによるTOEIC得点の差をみる. 2007 年度までに 4 年間多読授業を継続した本科 5 年生 以上の学生のうち, 同年度にTOEICを受験した $30 人$ の得点（年間自己ベスト）を, 読書量 (累積語数) で 表 2 に示す 3 群に分け, 比較した（図 5 )。外国人留 学生と英語圈への留学経験者は除いてある. また, 比 較のために, 英語圈への長期留学者の得点分布を付加 えた。

最も読書量の少ないA 群でも TOEIC平均435点であ り, 2007 年度の高専専攻科 2 年平均 373 点より 62 点高 く, 農・理工学部 4 年平均 420 点並みである. 授業時 間内しか読まない学生でも, 同世代理工系平均並みま で改善されることが分かる.

B 群では, 得点分布が高スコア側にシフトし，13人 中 12 人がTOEIC 400 点以上である. プログラム修了生 全員にTOEIC 400点を保証したい場合，この程度の読 書量を確保できれば，多読授業の追加で対応できる可 能性がある.

さらに, C群ではTOEIC平均が604点で, 英語圈留 学経験者と同水準である。体験の質が異なるので安易 に比較できないが, 少なくともTOEICで測定できる 基礎的な英語運用能力については, 数百万語の多読が 10 ケ月の長期留学に匹敵する可能性を示している.

この多読授業の実施状況を振り返り, 実践上のポイ

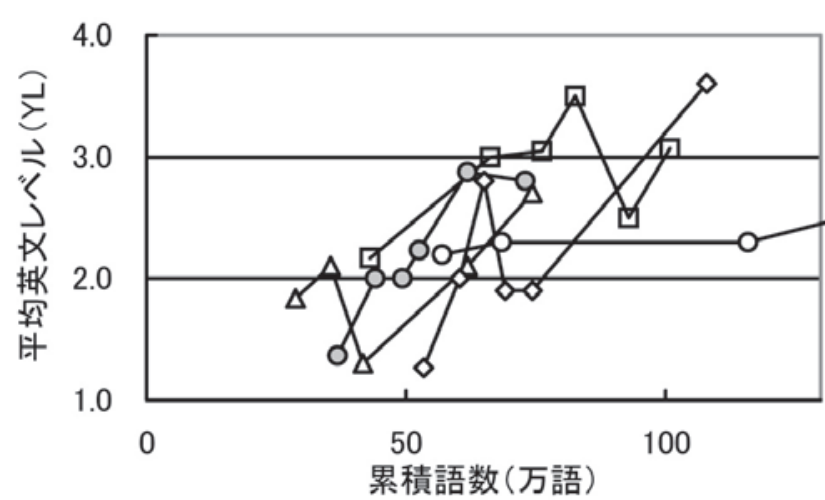

図 6 学生の読書履歴 (累積語数と平均英文レベル) ${ }^{12)}$

表 3 多読用図書の英文レベル13)

\begin{tabular}{|c|c|c|c|}
\hline YL & 基本語彙 & 英文の長さ & シリーズ例 \\
\hline 1.0 & $250 \sim 300$ & $700 \sim 2,000$ & FRL5, PGR1 \\
\hline 2.0 & $400 \sim 600$ & $3,000 \sim 7,000$ & OBW1, PGR2 \\
\hline 3.0 & 1,000 & $7,600 \sim 13,000$ & MMR3, OBW3, PGR3 \\
\hline
\end{tabular}

ントを明らかにするために, 詳しい記録の残っている 学生 6 名の読書記録を調查した。過去 2 年間, 4 ヶ月 毎の読書量（累積語数）とその時期に読んでいた平均 英文レベル（YL ${ }^{13)}$ 読みやすさレベル。 1 冊に英語が 1 語も書かれていない絵本：YL0.0から, 難解な一般 小説：YL 9.9まで）の関係を図 6 に示す. 累積語数と 平均英文レベルの関係は学生毎に異なるが, 大まかに みると, 累積50万語でYL 2.0, 累積100万語ではYL 3.0 辺りの英文を中心に読んでいることがわかる. 図 6 に は無いが, 学生は多読授業期間の前半 $(1 \sim 3$ 年目) には，更にやさしい（YL0.0～2.5の） レベルの英文 を中心に読んでいることも付記しておく.

英文レベル：YL 2.0（表 3）とは，大部分を基本語 彙400～600語で書かれた英文，抒抒よそ高校 1 年の 「英語講読」の副読本として使われるやさしい英文レ ベルである. また, 英語圈の小学校 1 年 $(\sim 2$ 年の始 め) 向け読本程度とも言える。

すなわち，この多読授業では，学生が極めてやさし い英文図書を 5 年かけて, 延々と読み続けていたこと がわかる。

学生の読書履歴は,「すらすら読めるやさしい英文 を読むように」という読書指導, TOEICによる外部 評価と，未読英文を用いた定期試験の影響を受けてい る. 例えば, 2008 年度専攻科 2 年の科目達成度目標の 一つは, 「基本語1000語水準（YL 3.2）の英文を，(毎 分100語以上で）連続して 1 時間以上読み続けること ができ，概要を把握することができる」に設定した． 定期試験では，YL 3.2，8,000語の未読英文を80分以内 に読み, 英文回収後に, その概要, やや詳しい内容に 関する質問に答えることを求めている（読書中のメモ は禁止). 
いくらやさしくても（基本語彙1,000語水準）長い 英文を読むことは意外に難しい，毎分 100 語以上で英 文を読むには，英文和訳をしている余裕はなく，8,000 語の未読英文を 80 分以内に読み切ることは（数十万語 の多読体験がなければ), 文系大卒者でも苦労する.

このことからも,多読による英語運用能力の向上は, 英語で直接意味処理ができるようになるためと考えら れる (図 1 )。多読でTOEICリーディング得点だけで なく，リスニング得点もバランスよく上昇することと も符合する.内容理解に集中した読書体験が, 低レベ ルの情報処理を徐々に自動化し，さらに処理負担が減 る（意識を集中しなくても処理できるようになる）好 循環を期待できる。こうなると, 学習者の認識は「読 書を楽しんでいるだけ」で英語運用能力が向上してし まう。専門科目の学習や研究の息抜きに英文読書を続 けることになり, 英語学習を専門としない工学系学生 の学習法として，極めて都合がよい.

ただし，学習者が「やさしい英文ならば読める」と 実感するために30～50万語以上の読書量が必要であ る. 大部分の受講生が無理なくこの量を読むためには, 以下の 2 点が不可欠である.

\section{1）授業時間内にコアとなる読書時間を確保する}

科目の課外として多読活動を課すだけで自律的継続 的読書を行う学生は，（少なくとも本校では）極めて 少数である。“忙しい”学生に英語多読を継続する習 慣を持たせるためには，正規科目として「多読授業」 を設定し，学生が定期的に読む時間を確保することが 不可欠である。豊田高専 $\mathrm{E}$ 科では， 45 分 $\times 30$ 週 $\times 5$ 年 間 $=113$ 時間の授業時間を確保した結果, 初めて過半 数の学生が（授業時間と同程度以上の読書を課外で 行い）累積読書量100万語を達成した。平均的な学生 の英語運用能力向上をTOEICで測定可能とするため には，少なくとも 3 年間の継続授業が必要で，できれ ば $4 \sim 5$ 年間の継続授業をカリキュラムに組み込みた い.

\section{2) やさしい英文図書から始める}

YL 1.0以下のやさしい英文図書から始めることも重 要である. 高瀬 ${ }^{14)}$ は, 5 つの大学生グループを比較し, 読書量が多かったグループの多読推進要因として, 初 期に大量のやさしい英文を読んだことを上げている. 我々の害践でも，学生に（5年間の）前半 3 年間に読 まれた英文レベルはYL $0.0 ２ .5$ である．特に，授業 初年度にYL 1.0未満の英文を読むことは, 日本語に翻 訳しながら読む読み方を英文から直接意味をくみ取る 多読の読み方に転換するためにも重要である。やさし い英文図書をスキップして，YL 2.0程度の図書から読 み始めると, いつまで経っても日本語に翻訳するクセ が抜けず，かえって運用能力の向上が遅れることが多 い.

最後に，多読と多聴を比較すると，特に入門期にお
いては,多読の方が導入しやすいことが分かってきた. 入門期の多読用図書には豊富な挿絵があるため, 翻訳 せずに（絵から）内容を理解することができることと， 学生が自分のペースで進めることができることが大き いのではないか．テキストを見ず，一度聞いただけで 内容を理解することのできる多聴教材のレベルは, 読 むことのできるレベルょりYLで約 2 程度低い. 入門 期には, 朗読音声のペースに合わせてテキストを読む, 聴き読みが有効であるが，テキストなしに聴く多聴を 無理なく始めるには，YL3.0程度の英文多読を楽しめ る能力が必要である.

\section{100 万語多読の特徵}

\section{1 ) 多読三原則}

豊田高専の多読授業実践は, 酒井の提唱する100万 語多読三原則 ${ }^{15)}$ (辞書は引かない/わからないところ は飛ばす／つまらなくなったらやめる）に従い実践さ れている。これは（日本語での読書のように）英文か ら直接（日本語に翻訳せずに）意味を汲み取り, 物語 の世界に入り込む（ことで, 英語使用の疑似体験をす る）ためのポイントをまとめたものである.

\section{2 ）読書量と英文のレベル}

100万語多読の読書量による学習者の変化は, 10 万語：(翻訳しない) 多読の読み方に慣れる（ACE： TOEIC形式の高校生向けテストでクラス平均が変 化), 30万語：やさしい英文なら読めると自覚 (ACE で個人得点変化, TOEICでもクラス平均が変化), 100万語：自律的に図書選択できる（TOEICで個人得 点変化を保証できる), 300万語：英語圈への留学経験 （1 年間）に匹敵する可能性あり，であり，逆に，10 万語程度で終わってしまうのでは，(学習者の感覚変 化以上の）効果を得ることは難しいと予想している.

また，100万語多読では日本語に翻訳して理解する のでなく，英文から「すーと読んで，すーと分かる」 ように読むためには，英文のレベルを極端にやさしく する必要があるとしており, それ以前の多読指導法と 異なっている。例えば，エジンバラ多読プロジェクト (EPER : Edinburgh Project on Extensive Reading) がDレベル, TOEIC 300点水準の学生（多くの高専生 のレベル）用としている英文のレベル16) は，100万語 多読では，100万語を読んだ学生（TOEIC 450点に達 している）に推蔦する英文レベルだった ${ }^{9}$.

\section{3 ）教員の役割}

多読授業では教員の役割が大きく変わる ${ }^{17)}$. 担当教 員は, 授業開始前に教材となるやさしい英文図書を自 ら読み, 個々の学生に合わせた推䳸図書を紹介できる よう豊富な教材知識を持つことが重要で, また, 初期 の教材（購入用予算）確保も重要な役割となる。

4) 多読用図書

豊田高専では, 初年度 600 冊で 1 クラスの多読授業 
を始め ${ }^{18)}$, 対象学年を拡大した 2004 年度には, 図書館 に約3,000冊のやさしい英文図書（YL 0.0～3.0を中心 に）を集めた．全学生の過半数が多読授業を受けてい る現在（2009年 7 月）では, 約 15,000 冊の図書を図書 館に所蔵している。戦略的な予算支出，外部資金の調 達が必要だが，LL，CALL等に比べれば，初期投資額 は少なく，始めやすいと言える。

\section{5 ) 成績評価}

学生の読書量で成績評価することは避けた方がよ い. 読書量を稼ぎたいとの気持ちが強くなり，ついつ い（長くて）難しい本を無理して読む学生が増えるか らである。一切評価をしない選択肢もあり得るが，著 者等は初見英文を用いたReading試験やTOEIC等の外 部試験による絶対評価を主とし，読書量による評価比 率を10\%以下と低くすることで，これを予防している.

\section{6 ）多読授業の導入状況}

現在, 工学系大学・高専では, 豊田, 沖縄, 東京他 の10校を超える高専，および，豊橋技科大で多読授業 が行われており，工学系英語教育における一つの潮流 となりつつある. 特に高専では, 3 年以上の長期継続 多読授業を組むことができるので, 成果を上げやすい.

\section{6. おわりに}

英語に対する苦手意識が強い工学系学生の運用能力 を向上させるには，従来にない新しい試みが必要であ る. 本稿では, 学生が「英語で考える」体験の量が改 善のポイントとの考え方から, 多読授業に注目した. また，同授業を 6 年間継続受講できるカリキュラム体 系を設計し（2009年度に完成），授業実践している豊 田高専の例を紹介した．多読授業は，極めてやさしい 英文図書の読書から始めることで，学生の自信を回復 し，また日本語に翻訳しない読書の楽しみを伝えるこ とができるので，英語に対する苦手意識の強い工学系 学生の教育には特に適している.

コアとなる読書時間を授業として確保し， 3 年以上 継続指導できれば，工学系学生の苦手意識を克服する ことも難しくないであろう

\section{参 考 文 献}

1 ）全国高専英語教育学会：TOEICに関する調查, Webページ, http://cocet.gifu-nct.ac.jp/survery/ toeic1.aspx, 2009, 参照日：2010-1-10

2) 全国高等専門学校英語教育学会, 高等専門学校に おける英語教育の現状と課題, pp.19-21, 2002

3 ) 森野数博: 高専は, 変わった!, 工学教育, $53-3$, pp. $87-92,2005$

4) TOEIC運営委員会, TOEICテストDATA \& ANALYSIS 2008, p9, p11, 2009

5 ) 西澤 一, 吉岡貴芳, 伊藤和晃, 深田桃代, 長岡美
晴: 豊田高専における英語多読授業の成果と課題, 第 7 回多読教育ワークショップ, 2008

6 ) 大貫 徹: 名古屋工業大学EGST教育の取り組み の成果と今後の課題について, 国立高専機構平成 18 ・19年度教育方法改善共同プロジェクト「高専 における国際性豊かな人材育成教育の現状と課 題」最終報告書, p34, 2008

7 ) 西澤 一, 吉岡貴芳, 杉浦藤虎 : インプット重視 の英語自習支援, その効果と限界, 高専教育, 28 , pp. $523-528,2005$

8 ) 斎藤 孝, 斎藤兆史, 日本語力と英語力, 中公新書, p19, 20, 2004

9 ）西澤 一, 吉岡貴芳, 伊藤和晃 : 英文多読による工 学系学生の英語運用能力改善, 電気学会論文誌 $\mathrm{A}$, $126-7$, pp. $556-562,2006$

10）高橋 要：TOEICに見る高専生の英語能力, H14 年度高専教育講演論文集, pp.147-150, 2002

11）白井恭弘：外国語学習の科学 - 第二言語習得論と は何か, 岩波新書, p135, 2008

12）西澤 一, 吉岡貴芳, 伊藤和晃: 英語運用能力に与 える英文読書量の影響 (2), 日本工学教育協会第 57 回年次大会, CD-ROM, 2009

13）古川昭夫他，めざせ1000万語！英語多読完全ブッ クガイド(改訂第 2 版), コスモピア, p11, 2007

14) Takase A. : The Two Most Critical Tips for a Successful Extensive Reading Program, Kinki University English Journal, 1, pp.119-136, 2008

15）酒井邦秀, 神田みなみ：教室で読む英語 100 万語, 大修館書店, p6, 2005

16) Day R. R. and Bamford J. : Extensive Reading in the Second Language Classroom, Cambridge University Press, 1998

17）堀 智子, 竹田恒美：英文多読に関する一考察： 英語教育のパラダイム・シフト, 高専教育, 28 , pp.351-356, 2005

18）吉岡貴芳, 西澤 一：理系クラスでの多読授業, 英 語教育, 2月号, pp.18-20, 2004

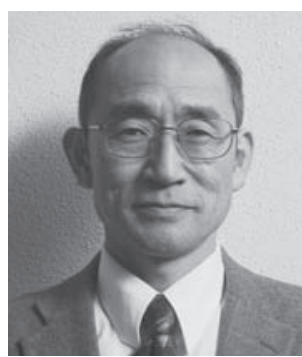

著 者 紹 介

西澤 一

1979年＼cjkstart豊田高専電気工学科卒業 1983年 豊橋技科大大学院修士課程修了 日本ガイシ(株)第三研究所 1992年 豊田高専電気工学科助教授 現 在 電気. 電子システム工学科教授 博士 (工学), 特別教育士 (工学・技術) 電気学会会員

連絡先 nisizawa@toyota-ct.ac.jp 